\title{
O CORPO É UMA GRANDE RAZÃO: LIBERDADE, CONSCIÊNCIA E NATUREZA EM NIETZSCHE
}

\author{
THE BODY IS A GREAT REASON: \\ FREEDOM, CONSCIENCE AND NATURE IN NIETZSCHE
}

\author{
Joana Brito de Lima Silva \\ Pós-doutoranda em Filosofia - PPGFIL UFJF
}

\begin{abstract}
RESUMO: O artigo apresenta as noções de liberdade e natureza na filosofia de Nietzsche a partir de aforismos escritos em Humano, demasiado humano e Aurora, nos quais o filósofo afirma a total irresponsabilidade humana (destino) e, ao mesmo tempo, exalta o agir em curso na natureza; o impasse entre ação livre e necessária repercute em A Gaia Ciência, nas reflexões a respeito da consciência ou intelecto: este seria o mais frágil órgão do corpo humano e, portanto, incapaz de comandar o agir. Nietzsche, porém, não afirma nenhum determinismo regente das ações; ao contrário, trata-se de mostrar o desconhecido mundo subjetivo, no qual vivemos; por isso, em Assim falou Zaratustra, o corpo é chamado de grande razão, em contraste à pequena razão da consciência, e a vontade de poder atravessa cada movimento corporal: orgânico, inconsciente ou intencional. Enfim, o recorte da filosofia de Nietzsche, percorrido no artigo, propõe uma reflexão complementar entre natureza e liberdade, sustentada sobre três pilares: o puro acaso (indeterminação), a inocência da natureza (sem responsabilidade ou culpa) e a liberdade humana (não tomar a si mesmo como fato consumado).
\end{abstract}

Palavras-chave: Nietzsche; Natureza; Liberdade; Corpo.

\begin{abstract}
The article presents freedom and nature in Nietzsche's philosophy, based on aphorisms written in Human, All Too Human and The Dawn OfDay, in which the philosopher affirms the total human irresponsibility (destiny) and, at the same time, exalts the current action in nature; the impasse between free and necessary action has repercussions at The Gay Science, in reflections about conscience or intellect: the most fragile organ of the human body and, therefore, incapable of commanding action. Nietzsche, however, does not affirms any governing determinism of actions; on the contrary, it is about showing the unknown subjective world, in which we live; then, in Thus spoke Zarathustra, the body is called as "great reason", in contrast to the small reason of consciousness, and also the will to power runs through every bodily movement: organic, unconscious or intentional. Finally, this part of Nietzsche's philosophy, covered in the article, proposes a complementary
\end{abstract}


reflection between nature and freedom, based on three pillars: pure chance (indeterminacy), the innocence of nature (without responsibility or guilt) and human freedom (no take yourself for granted).

Key-words: Nietzsche; Nature; Freedom; Body.

O nome de Nietzsche, fora do ambiente acadêmico, pode evocar lugares-comuns ou fórmulas aparentemente fáceis e impactantes, dependendo da utilização e do contexto no qual aparece (numa busca simples na internet, por exemplo). Deus está morto. Não há fatos, apenas interpretações. Super-homem. O que não me faz morrer me fortalece... São alguns exemplos de temáticas mais comuns associadas a Nietzsche, citadas aqui aleatoriamente. O estilo do filósofo é um dos fatores que facilitaria essa aparente popularização. Nietzsche escrevia a maior parte de seus escritos no formato de aforismo, isto é, pequenos parágrafos com frases fortes e, também, utilizava imagens ricas em metáforas; misturava personagens de romances e tragédias gregas, com filósofos, músicos, artistas, e até mesmo criava heróis para protagonizarem suas ideias, como o seu Zaratustra. De fato, o autor procurava construir um estilo próprio para se contrapor ao rigor dos sistemas filosóficos fechados, e esta decisão estilística provoca um efeito, no mínimo, inesperado em sua filosofia: Nietzsche, na contemporaneidade, aparece transformado em ícone de moda, um astro pop. Há, em seu nome, tanto manuais de autoajuda com alto índice de vendas, como "Nietzsche para estressados: 99 doses de filosofia para despertar a mente e combater as preocupações" (de Allan Percy, 2009, Ed. Sextante), quanto diversos blogs e produtos à venda com sua imagem estilizada (bolsas, quadros e camisetas com estampas do autor e caricaturas dele vestido de Superman, herói das histórias em quadrinhos, etc.). ${ }^{1}$

Nada impede tais apropriações; o problema não é o uso capitalista de sua imagem - penso que o filósofo não se importaria - e o fenômeno comprova a

\footnotetext{
${ }^{1}$ Conforme pesquisa simples feita em mecanismos de busca na internet: https://oblogdomaluco.com.br/o-dia-em-que-entrevistei-nietzsche-e-os-conselhos-que-ele-me-pediu-pararepassar-para-voce-um-dos-textos-mais-lidos-do-blog-sobre-a-filosofia-e-a-vida/ https://blogdoims.com.br/o-abraco-de-nietzsche/ https://www.lojadacamisa.com.br/loja/busca.php?loja=737444\&palavra_busca=nietzsche
} 
afirmação de que no capitalismo tudo se transforma em mercadoria ${ }^{2}$. E, antes que transpareça algum moralismo ou discurso elitista, cabe esclarecer que a crítica à popularização de Nietzsche volta-se às possíveis distorções feitas do pensamento do autor. Nietzsche, quando anuncia o além-do-homem, Übermensch, não pensava em se tornar um ícone pop e, tampouco, defendia o clamor por super-heróis para aplacar os males da sociedade. Ao contrário, sua filosofia é basicamente um apelo para que as pessoas parem de viver como gado ou ovelhas, num rebanho, guiadas por um pastor (ou herói) a conduzi-las. O filósofo repudia categoricamente qualquer tipo de rebanho, onde todas as pessoas seguem a mesma direção, se comportam do mesmo jeito, pensam e praticam ideias e valores sem questiona-los, andam de acordo com as ordens dadas, possuem a mesma aparência e consomem produtos padronizados; em suma, elas simplesmente seguem o rebanho, sem reflexão: aderem às modas, repetem as mesmas opiniões, concordam com tudo e sentem-se bem neste nivelamento. Portanto, o rebanho é o avesso da filosofia nietzschiana - e a popularização massiva, geralmente, tem um efeito alienante.

Nesse contexto, a sociedade de rebanho transforma a liberdade num produto (ou ato) de consumo e a limita através de imperativos morais e crenças fundadas no livre arbítrio. E, ao contrário das noções comuns atribuídas à liberdade, a filosofia nietzschiana considera que o primeiro passo para uma efetiva libertação é libertar-se do rebanho. Mas como é possível ser livre nesse ambiente nivelador? Este é o desafio encarado por Nietzsche ao pensar a liberdade fora do âmbito moral. De fato, o horizonte aberto com as críticas de Nietzsche à religião, à moral e à metafísica, permite avançar na direção oposta ao rebanho e às visões de mundo padronizadas; assim, a filosofia nietzschiana estabelece um ambiente de perspectivismo, no qual não cabem preceitos morais, crenças do senso comum e pensamentos limitados: "o mundo tornou-se novamente infinito para nós, na medida em que não podemos rejeitar a possibilidade de que ele encerre infinitas interpretações" (NIETZSCHE,

\footnotetext{
${ }^{2}$ Em O Manifesto Comunista, Marx e Engels afirmam: "Tudo que era sólido desmancha no ar, tudo que era sagrado é profanado” (MARX; ENGELS, 2008, pp. 15-16); os autores se referem às transformações capitalistas geradas pela ascensão da burguesia sobre as relações de trabalho, mercado, etc. disponível em: https://www.expressaopopular.com.br/loja/wp-content/uploads/2020/02/manifesto-comunista-EP.pdf
} 
2004c, p. 278; aforismo 374 de $A$ Gaia Ciência) ${ }^{3}$. Então, mencionar, aqui, a apropriação pop do filósofo é apenas um alerta para evitar uma postura incompatível com a filosofia de Nietzsche - além de ser uma forma de introduzir esse artigo e situar o pensamento nietzschiano: ele está fora do rebanho, além do tempo e livre das amarras acadêmicas.

Assim, trata-se de apresentar, nesse artigo, como Nietzsche entende natureza e liberdade, corpo e consciência, acaso e destino; e, desde já, nota-se que a perspectiva assumida pelo filósofo parte do princípio de que nesse jogo, vivido diariamente, não é possível controlar as consequências de cada jogada. Necessidade e liberdade seguem juntas na formulação a respeito do destino e do acaso; e, na mesma medida, a consciência não pode conhecer ou prever os resultados das ações (causa e efeito), assim como o corpo não obedece a lógica da causalidade. Enfim, propõe-se discutir tais ideias de Nietzsche através de quatro obras suas ${ }^{4}$ : Humano, demasiado humano, Aurora, A Gaia Ciência e Assim falou Zaratustra, evitando, sobretudo, os clichês, os rótulos preconceituosos (filósofo niilista, ateu, misógino) e as simplificações do rebanho.

Natureza, inocência e acaso

A partir de 1876, Nietzsche vivencia um momento de errância filosófica; não leciona mais na Universidade de Basiléia, Suíça, como fizera entre 1870-75, época de O Nascimento da Tragédia e de escritos sobre os gregos pré-socráticos, entre outros temas trabalhados pelo autor. Contudo, em suas errâncias extra acadêmicas, o filósofo não se afasta da Filosofia. Nietzsche vive um período cético no qual suspeita de tudo e de todos. Humano, demasiado humano e Aurora são obras escritas nesse espírito de confrontar e se contrapor às filosofias da Modernidade; por isso, conceitos como responsabilidade, liberdade, sujeito, moral, destino, Ser e natureza são tratados

\footnotetext{
${ }^{3}$ É consensual, ao citar trechos da obra nietzschiana, se referir sempre ao número do aforismo citado, seguido da sigla da obra em questão; contudo, para manter o padrão de citações da Revista, também será incluída a referência habitual para artigos.

${ }^{4}$ Conforme nota anterior, as siglas para as obras serão, respectivamente: HDH (2004a), Au (2004b), GC (2004c), Za (2005).
} 
sob suspeita e, muitas vezes, contrariam o sentido comum atribuído a cada uma dessas palavras. Nesses livros, o alvo da crítica nietzschiana é voltado a atingir a origem de noções e conceitos filosóficos tradicionais; por isso, o modo pelo qual o autor relaciona liberdade, destino e natureza evidencia claramente seu método da suspeita, diferenciando-se, cada vez mais, da tradição filosófica estabelecida (Platão, Kant, etc.).

É assim que Nietzsche nos surpreende ao afirmar: "Nosso destino dispõe de nós, mesmo quando ainda não o conhecemos; é o futuro que dita as regras do nosso hoje" (Prólogo de HDH; 2004a, p. 13). A sentença questiona os modos de ser livre e de ser responsável por si quando somos apropriados pelo destino - nós o desconhecemos e, no entanto, o realizamos em nossos atos, afirma o filósofo; em Humano, o autor propõe uma grande libertação: caberá aos espíritos livres se libertarem de antigas crenças e preconceitos a respeito do agir humano e das consequências incontroláveis das ações. Desenrola-se, assim, a noção de Nietzsche a respeito da liberdade; o filósofo emprega metáforas e sarcasmo para descrevê-la no aforismo 39, intitulado Fábula da Liberdade Inteligivel; trata-se da fábula segundo a qual somos responsabilizados e punidos por nossos atos que, em consequência, determinariam o nosso próprio Ser (caráter). É a crença no livre arbítrio, enquanto opções (limitadas) de agir, conforme uma escala moral pré-estabelecida, que está em jogo.

A ilusão de liberdade, criticada por Nietzsche, é a limitação imposta pela moral ao agir humano, na medida em que ela determina como se pode (e deve-se) agir para, em seguida, julgar o caráter de quem age e fixar tipologias de ser (este homem é bom, aquele outro é mau). Porém, Nietzsche afirma: "não se pode tornar o homem responsável por nada, seja por seu ser, por seus motivos, por suas ações ou por seus efeitos" (af. 39, HDH; 2004a, p. 48). Nietzsche refuta, no mesmo aforismo, a noção de liberdade inteligível, de Schopenhauer, segundo a qual a humanidade estaria condenada a remorso e arrependimento após agir; por isso, as ações resultariam em mal-estar, como se houvesse um querer racional direcionando a vontade (como se ela, a vontade individual, fosse previsível e controlável). Ao 
contrário do que defendia Schopenhauer, liberdade e inteligibilidade são incompatíveis, pois, segundo Nietzsche, não há raciocínio, controle ou mesmo responsabilidade na vontade (livre) que direciona o agir. Pode parecer leviano de sua parte descartar esses fatores, mas logo torna-se compreensível o sentido moral que o filósofo atribui à responsabilidade: "Ninguém é responsável por suas [próprias] ações, ninguém responde por seu ser; julgar significa ser injusto" (af. 39, HDH; 2004a, p. 49), afirma Nietzsche. Ser responsabilizado, neste sentido, é um julgamento moral, uma condenação que gera afetos negativos (ressentimento, remorso, malestar). De fato, é importante lembrar que o filósofo está dialogando com os moralistas de sua época, especialmente aqueles sob influência do imperativo categórico de Kant e dos mandamentos judaico-cristãos (doutrina do livre arbítrio). E, sobretudo, o alvo da crítica nietzschiana é Schopenhauer; a defesa schopenhaueriana da compaixão enquanto sentimento moral gerado após ações altruístas torna-se um dos enganos da liberdade inteligível; tanto no aforismo citado acima quanto em outros de Humano (aforismos 47 e 50, por exemplo), o autor mostra que a suposta ação livre é falível e, em muitos sentidos, a moral da compaixão resultante da liberdade inteligível é o contrário do que defende Schopenhauer: segundo Nietzsche, o uso doentio da compaixão pode despertar o sentimento de pena, chantagem, poder e dívida. ${ }^{5}$

Nietzsche rejeita a responsabilidade atrelada às ações humanas para se apropriar do conceito de liberdade sem o peso moral atribuído a ele, pois, em sua concepção, as doutrinas moralistas sustentam posicionamentos que forçam o humano a se distanciar de sua animalidade, negam suas pulsões naturais e reprimem os impulsos de força e expansão. A crítica nietzschiana é uma revolta contra o esquecimento das origens telúricas humanas, esquecimento que transforma os homens em animais domesticados, adestrados, aptos a viverem em rebanho, nivelados, passivamente disciplinados. ${ }^{6}$ Posicionar-se contra a responsabilidade e a condenação

\footnotetext{
${ }^{5}$ Sobre o conceito schopenhaueriano de compaixão e as respectivas críticas de Nietzsche indico meu artigo "Vontade e moral em Schopenhauer: algumas suspeitas nietzschianas" (LIMA SILVA, 2015), disponível em: https://cchla.ufrn.br/ppgfil/PDF/livros/IV-CIM-Natureza-e-Metafisica.pdf

${ }^{6}$ Sobre o esquecimento da gênese humana - de sua origem marcada por violência, conflito e barbárie indico o livro Nietzsche: o humano como memória e promessa, especialmente o capítulo "Notas sobre o conceito de natureza humana” (GIACOIA, 2014), usado como referencial teórico da minha palestra e do artigo aqui apresentado.
} 
do ser ao agir (julgar é ser injusto), é também um modo de denunciar a situação de seu tempo: século XIX, industrialização capitalista, autoritarismos de Estado e da Igreja, guerras, promessas de modelos políticos (nacionalismos, socialismo utópico, futuros regimes nazista e fascista), dentre outros fatores da sociedade de rebanho, que promovem o controle social e não a libertação.

Ainda assim - tendo em vista esse contexto -, o desafio proposto por Nietzsche nos desafia: como agir livremente sem assumir responsabilidades? De que liberdade se trata? E qual é a possibilidade de ser livre sem ser responsável? Ora, as ações não seriam decisões escolhidas e assumidas? Para encontrar respostas é preciso compreender o que é necessidade, segundo Nietzsche, e como ela se relaciona à natureza. De acordo com o autor, tudo é necessário no que tange ao natural: "À vista de uma cachoeira, acreditamos ver nas inúmeras curvas [...] o arbítrio da vontade e do gosto; mas tudo é necessário, cada movimento é [...] calculável" (aforismo 106, $\mathrm{HDH}$; 2004a, p. 81). É necessário que a água escorra através das pedras e se jogue abismo abaixo, sem querer ou pensar - e sem pesares. A natureza é essencialmente necessária e, por necessidade, ela segue um percurso que escapa ao controle (racional) da escolha. Portanto, liberdade, em Nietzsche, não significa escolher, mas seguir o próprio ser (natureza). Noutras palavras, o desenrolar do movimento (humano e telúrico) já está em curso, do mesmo modo que uma cachoeira escorre suas águas e que um vulcão entra em erupção. É um processo irrefreável.

Natureza é necessidade. E, lado a lado à necessidade, está a "total irresponsabilidade do homem por seus atos e seu ser" (aforismo 107, HDH; 2004a, p.81). Nietzsche apresenta a inocência em contraposição à responsabilidade: ser inocente de si mesmo é, segundo o filósofo, "a gota mais amarga que o homem do conhecimento tem de engolir, se estava habituado a ver na responsabilidade e no dever a carta de nobreza de sua humanidade" (af. 107, HDH; 2004a, p.81). O agir se torna fruto de uma necessidade que escapa do controle de quem age. São os motivos que decidem acerca de nós, e não o contrário. Aqui, torna-se mais clara a sentença citada anteriormente, quanto ao destino dispor do futuro sem que se saiba, previamente, qual rumo será seguido. Nietzsche desconstrói, pouco a pouco, a noção 
moderna de subjetividade, na medida em que retira de cena a razão, a responsabilidade e a culpa. Não há ações boas ou más, sejam quais forem os afetos em jogo (amor, ódio, vingança, compaixão, sacrifício ou salvação), pois os julgamentos são frutos da vontade humana de controlar e definir uma escala de valores imutável (moral, caráter). Porém, o fluxo dos acontecimentos segue um ritmo incontrolável, do ponto de vista individual, e de nada adiantará tecer julgamentos posteriores (definir o Bem e o Mal a partir do agir e da vontade).

Neste ponto, o desafio proposto por Nietzsche torna-se um enigma: sim, há liberdade, desde que não seja a liberdade calculista da racionalidade. Trata-se da liberdade guiada pela dupla natureza-necessidade (ou trio, caso inclua-se aí a inocência ou irresponsabilidade). Nietzsche apresenta, numa bela imagem, qual é, afinal, a liberdade dos espíritos livres: "A borboleta quer romper seu casulo, ela o golpeia, ela o despedaça: então é cegada e confundida pela luz desconhecida, pelo reino da liberdade" (af. 107, HDH; 2004a, p. 82). Neste aforismo Nietzsche convida os leitores a viverem a experiência da natureza: quem experenciar o mundo com a mesma inocência de uma borboleta, libertando-se do próprio casulo, poderá sentir os primeiros raios solares que irradiam liberdade. Em suma, "Tudo é inocência" (af. 107, $\mathrm{HDH}, 2004 \mathrm{a}$, p. 83) nesse ato libertador.

Nietzsche constrói, assim, novos caminhos para novas auroras, conforme afirma: "um novo hábito, o de compreender, não amar, não odiar, abranger com o olhar, pouco a pouco se implanta em nós no mesmo chão" - e prossegue, num tom profético: "e daqui a milhares de anos talvez seja poderoso o bastante para dar à humanidade a força de criar o homem sábio e inocente (consciente da inocência), da mesma forma regular como hoje produz o homem tolo, injusto, consciente da culpa" (af. 107, HDH, 2004a, p. 83). O homem tolo, segundo o filósofo, é o religioso subjugado ao livre arbítrio; homem que almeja ser algo que não é: ele quer ser Deus. Segundo Nietzsche, a religião judaico-cristã exerce sobre os devotos um peso insuportável, especialmente quando exige um comportamento digno de sua divindade, incompatível com as falhas e faltas humanas: "é porque olha nesse espelho claro que o seu ser parece tão turvo, tão incomumente deformado" (af. 132, 
$\mathrm{HDH}, 2004 \mathrm{a}$, p. 101), noutras palavras, espelhar-se em Deus geraria, nos homens, o senso de justiça punitiva, responsabilidade e culpa, impedindo a libertação do homem do casulo moral onde se encontra aprisionado.

Da inocência extrair liberdade; o enigma nietzschiano começa a ser desvendado: ser humano (demasiadamente) é ser natureza, e não há racionalidade na natureza, há necessidade puramente inocente, não racional, genuinamente livre. Compreende-se, então, porque Nietzsche dedica o livro Humano, demasiado humano aos espíritos livres; o filósofo dirige-se a eles: "Seja você como for, seja sua própria fonte de experiência! Livre-se do desgosto com seu ser" (af. 292, HDH; 2004a, p. 195). E o que é o desgosto, senão um efeito da culpa e do remorso gerados pela responsabilização individual? Nota-se, novamente, o perspectivismo no olhar diferenciado de Nietzsche sobre as noções de natureza, necessidade e liberdade: não ser responsável e não se espelhar em Deus são formas de libertação dos imperativos morais. Distanciar-se, para olhar em perspectiva, aproximar-se para conferir outras angulações possíveis, não se apegar à primeira vista e, menos ainda, render-se à cegueira. Nesse sentido, são os andarilhos que desempenham com maior perspicácia o perspectivismo nietzschiano: "Quem alcançou em alguma medida a liberdade da razão, não pode se sentir mais que um andarilho sobre a Terra - e não um viajante que se dirige a uma meta final: pois esta não existe" (af. 638, HDH; 2004a, p. 306). Não há metas, nem fins, nem tábuas de valores - tampouco evolução ou teleologia. Por isso, a errância (o ser errante) caracteriza com precisão a inocência do vir-a-ser explanada ao longo da obra pelo autor.

Porém, ainda parece contraditório afirmar que não há fins certos ou destino a se cumprir, quando lembramos, mais uma vez, de sua afirmação sobre o futuro ditar as regras do hoje e que tudo se move num rumo necessário (o fluir da cachoeira, a borboleta no casulo, etc.). Cabe, então, acrescentar outro componente ao trio irresponsabilidade-necessidade-liberdade: o acaso. Sem a noção de acaso a interpretação nietzschiana corre o risco de ser distorcida em mero determinismo. E não se trata de determinação. É justamente a indeterminação que está em foco. Andarilhos e errantes enfrentam os infortúnios de um vagar imprevisível, entre 
dificuldades inesperadas e prazeres inusitados; Nietzsche recorre à imagem dos andarilhos errantes justamente para ilustrar a ideia de imprevisibilidade da vida e das ações humanas: "Sem dúvida esse homem [andarilho] conhecerá noites ruins, em que estará cansado e encontrará fechado o portão da cidade que lhe deveria oferecer repouso [...]; mas depois virão, como recompensa, as venturosas manhãs de outras paragens [...]; eles buscam a filosofia da manhã" (af. 638, HDH; 2004a, p. 306). Com este aforismo, Nietzsche termina Humano, demasiado humano, anunciando sua próxima publicação, também dedicada à arte da suspeita.

A filosofia da manhã, Aurora brilhante que se renova todo dia, coloca sob suspeita a moral, a religião e a verdade metafísica. Posicionando-se contra seus antagonistas (Platão, Kant, Schopenhauer etc.), Nietzsche rejeita a infelicidade e a culpa geradas na ilusão do livre arbítrio (judaico-cristão) e no imperativo categórico, pois ambos culpabilizam e punem o humano por seus eventuais erros. De fato, ao esbravejar contra a responsabilidade, o filósofo está, também, revelando o "desconhecido mundo do sujeito" (aforismo 116 de Aurora), ou a ignorância de cada pessoa sobre si mesma. O desconhecimento em relação a si reverbera na incompreensão do próprio querer, do pensar e do agir, conforme afirma: "Não é justamente isso a 'terrível' verdade: que o que se pode saber de uma ação não basta jamais para fazê-la, que a ponte do conhecimento ao ato não foi lançada nem uma vez até hoje?" (aforismo 116, Au; 2004b, p. 89). Novamente, a irresponsabilidade é evocada para refutar o equívoco da ação racional, pois os "atos não são jamais aquilo que nos parecem ser!" (af. 116, Au; 2004b, p. 89); a responsabilidade culpabiliza o agente e faz com que o sentimento de culpa e remorso determine seu caráter (considerado imutável, conforme visto na crença da liberdade inteligível, de que o agir determina o ser e viceversa, no aforismo 39 de $\mathrm{HDH}$, já discutido acima).

Em Aurora, Nietzsche aprofunda a noção de acaso que rege o mundo, a vida, as ações humanas e o próprio destino. Assim, no aforismo 130, o filósofo define o jogo entre inocência e necessidade a partir da ideia de que o acaso é regido por "gigantes estúpidos" que lançam dados para os "inteligentes anões" jogarem o jogo da necessidade. O acaso é o "poderoso reino da estupidez cósmica", afirma 
Nietzsche, num exercício de imaginação, no qual tais personagens entram em cena juntos: "nós, inteligentes anões, com nossa vontade e nossos fins, somos irritados, atropelados, muitas vezes pisoteados até a morte pelos gigantes estúpidos, mais que estúpidos, que são os acasos" (aforismo 130, Au; 2004b, p. 98). Nós, humanos (anões inteligentes), construímos teias frágeis em nossas ações, e os inocentes e irresponsáveis gigantes, com suas mãos pesadas e toscas, as destroem sem nem perceberem - esta é a inocência do acaso que rege tanto a natureza quanto a liberdade.

Contudo, segundo Nietzsche, alguns anões tentaram ser mais espertos que os gigantes e criaram a fábula do Bom Deus para se protegerem dos acasos e, ainda, justificarem os resultados de suas ações, como se esperassem recompensas de seus atos. Sem perceberem que as teias trançadas e sustentadas pela divindade eram frágeis, os espertos anões se surpreenderam quando não conseguiram escapar dos infortúnios do acaso; ora, suas boas ações não foram recompensadas pelo Bom Deus! Então, pensavam, inconformados: por que eram punidos? Como explicar o mau causado pelo romper de um fio das teias tecidas por Deus, sendo essa divindade (por princípio) tão boa e perfeita? Ou: como Deus poderia se descuidar assim de nós (que o criamos), meros anões enfrentando gigantes? São questionamentos que motivam a humanidade desde seus primórdios, e a criação de deuses e sistemas religiosos tentam suprir tais questões, mas sempre resta uma abertura para o acaso e os imprevistos. Assim, Nietzsche explica a fábula do Bom Deus mostrando suas falhas evidentes "havia ali uma contradição: se nosso entendimento não pode apreender o entendimento e os fins de Deus, como apreendeu ele essa natureza do seu entendimento? e essa natureza do entendimento de Deus?" (af. 130, Au;; 2004b, p. 99). Noutras palavras, se não entendemos a vontade divina como é possível deduzir, de algo que não entendemos, qualquer tipo de explicação e, mesmo, como criar um conceito racional de um deus se ele é, por definição, impossível de ser compreendido racionalmente? Nietzsche traduz tanto a inquietação humana ante o acaso quanto a indignação da humanidade frente à falta de proteção divina numa simples imagem: como entender a telha que cai do telhado e atinge os anões? Como ela pode ser 
lançada pelo amor divino? Quem protegerá os anões dos ameaçadores gigantes? Afinal, qual é a Lição da fábula? Nietzsche esclarece:

[...] em nosso suposto reino especial de fins e de razão governam também os gigantes! E nossos fins e nossa razão não são anões, mas gigantes! $\mathrm{E}$ nossas teias são rasgadas tão frequentemente e tão grosseiramente por nós mesmos como por uma telha! [...] Então há apenas um reino, o dos acasos e da estupidez? [...] sim, talvez haja somente um reino, talvez não exista vontade nem finalidade, e nós apenas as imaginamos. As mãos férreas da necessidade, que agitam o copo de dados do acaso, prosseguem jogando por um tempo infinito: têm de surgir lances que semelham inteiramente a adequação aos fins e a racionalidade. Talvez nossos atos de vontade e nossos fins não sejam outra coisa que tais lances - e nós somos apenas muito limitados e vaidosos para apreender nossa extrema limitação: a saber, que nós mesmos agitamos o copo de dados com mãos férreas, que nós mesmos, em nossas ações mais intencionais, nada fazemos senão jogar o jogo da necessidade. Talvez! (aforismo 130, Au; 2004b, pp. 99-100).

No aforismo citado, Nietzsche consegue alinhar necessidade e acaso para criticar o determinismo racional e religioso. O filósofo desmascara, ao mesmo tempo, a ilusão de que haveria uma divindade guiando e protegendo os homens dos infortúnios da vida, e a pretensão de autoconhecimento, impressa nas crenças de quem nunca duvidou do eu penso, eu quero, eu sou. Nesse movimento de destruição de certezas, a pergunta colocada no aforismo citado a seguir, resume claramente a crítica nietzschiana à noção moderna de subjetividade; "mas vocês sabem o que querem?" - pergunta Nietzsche, em tom de ameaça: "Não temem reencontrar, na caverna de todo conhecimento, o seu próprio fantasma, como uma trama de que a verdade se mascarou perante vocês?" (af. 539, Au; 2004b, p. 264). Desse modo, Nietzsche reafirma o desconhecido mundo do sujeito, para mostrar que a liberdade não atua racionalmente sobre a vontade, e o acaso direciona o percurso do destino (as mãos férreas da necessidade jogam os dados lançados). Saber o que se quer, nesse sentido criticado por Nietzsche, representa o desejo humano de controlar as jogadas e de conhecer os lances de dados; no entanto, o resultado é imprevisível, desconhecido, e somente será sabido após sua execução; esta analogia aos jogos de azar (uma das definições de acaso) permite compreender como o filósofo se destitui da noção moderna de sujeito e constrói outra concepção de subjetividade, aliada aos fatores já discutidos: a inocência da necessidade atuante na natureza e o acaso que rege a liberdade humana. 
Resta-nos, agora, perguntar a Nietzsche sobre o que somos livres para fazer. É o título do aforismo 560 de Aurora; na verdade, não é uma pergunta, mas uma sentença colocada pelo filósofo sem qualquer interrogação. Nietzsche nos coloca frente a um horizonte aberto de possibilidades sem escapatórias: não é mais possível se esconder atrás do livre arbítrio e demais recursos da moral e da religião (fábulas do Bom Deus e da liberdade inteligível). É, também, impossível proibir uma borboleta de sair do casulo ou impedir uma cachoeira de desaguar; Nietzsche mostra que a natureza está de mãos dadas à necessidade, e assim o livre agir segue um curso desconhecido; torna-se injusto acusar e julgar alguém por suas ações, extraindo delas seu ser (ou caráter), pois o agir escapa do agente no mesmo instante em que a ação passou: esta é a irresponsabilidade de ser livre. Não se trata de evolução ou determinismo, é o jogo da inocência que está em curso. A natureza da borboleta faz com que ela saia do casulo sem pensar, querer ou decidir. É a inocência do gigante que leva sua mão a romper as teias fragilmente tecidas pelos anões (e atribuídas a Deus). Não há culpa, nem castigo, nem remorso ou arrependimento. Portanto, a resposta de Nietzsche sobre o que somos livres para fazer é mais uma provocação, expressa noutra bela imagem da natureza:

\footnotetext{
Pode-se lidar com os próprios impulsos como um jardineiro [...]; pode-se também deixar a natureza agir e apenas providenciar aqui e ali um pouco de ornamentação e limpeza... pode-se, enfim, sem qualquer saber e reflexão, deixar as plantas crescerem com suas vantagens e empecilhos naturais e lutarem entre si até o fim - pode-se mesmo ter alegria com essa selva, e querer justamente essa alegria, ainda que traga também aflição. Tudo isso temos liberdade para fazer; mas quantos sabem que temos essa liberdade? Em sua maioria, as pessoas não crêem em si mesmas como em fatos inteiramente consumados? (af. 560, Au; 2004 b, p. 279).
}

O aforismo citado, um dos últimos de Aurora, permite o encadeamento das ideias ora apresentadas para interpretar as apropriações nietzschianas de liberdade e destino: se é o futuro que dita o nosso hoje, isso não significa sucumbir ao determinismo ou ao peso do passado (responsabilidade moral). É a liberdade, não racional, mas puramente inocente e necessária, que rege nosso agir e nosso querer. $\mathrm{O}$ acaso faz com que os dados lançados pelas mãos férreas da necessidade coincidam com nossa vontade e, assim, assumimos os lances jogados; afinal, como nós, inteligentes anões, podemos fazer frente a aterrorizantes gigantes? A intimidação, 
contudo, permite-nos uma atitude de admiração da natureza, como jardineiros admirados com o nascer da borboleta e com os raios de Sol que aquecem as gotas de orvalho numa folha; atitude inocente e necessária - ou, simplesmente, livre. A liberdade está, finalmente, em não se tomar a si mesmo como um fato inteiramente consumado, embora reste um desconhecimento próprio a ser descoberto a cada instante.

Corpo e consciência: grande e pequena razão

Após Humano e Aurora, Nietzsche vivencia um momento de júbilo, superando as crises que abalaram, anteriormente, a sua saúde; é justamente nesse período de alegria, entre 1881 e 1886, que o filósofo escreve A Gaia Ciência e Assim falou Zaratustra, obras nas quais apresenta seu pensamento abissal, o eterno retorno; em Ecce Homo, escrito em 1888, Nietzsche relata a ocasião na qual sentiu-se acometido pela visão do eterno retorno, "a mais elevada forma de afirmação que se pode em absoluto alcançar" (NIETZSCHE, 2004d, p. 82). A sublime experiência do filósofo o motiva a escrever uma filosofia gaya, alegre e mais compatível com a elevação então alcançada; dessa forma, além das suspeitas e do perspectivismo já praticados nos livros anteriores, o autor convida seus leitores a dançarem uma nova música (conf. aforismo 383, GC). Trata-se de continuar na mesma trilha, aberta nas obras anteriores: a crítica à tradição metafísica e a construção de uma filosofia própria, uma transvaloração de todos os valores. É nesse ritmo que, no prólogo de GC, Nietzsche lança uma dúvida a respeito de todo conhecimento filosófico: será que "até hoje a filosofia, de modo geral, não teria sido apenas uma interpretação do corpo e uma má-compreensão do corpo"? (NIETZSCHE, 2004c, p. 12). ${ }^{7}$

Escrito em 1886, o prólogo de A Gaia Ciência questiona a tradicional separação corpo e alma na história da filosofia - existente não apenas em seus primórdios, com Sócrates e Platão, ou em Descartes, mas, segundo Nietzsche, estaria presente em

\footnotetext{
${ }^{7}$ Sobre o tema, consultei Nietzsche e o corpo, referencial utilizado na elaboração da palestra e do artigo; indico especialmente o capítulo III, sobre uma nova relação consciência-corpo (BARRENECHEA, 2017).
} 
todos os sistemas filosóficos, na medida em que se referem a um mundo verdadeiro em contraposição a outro que seria mera aparência do primeiro (oposição entre coisaem-si, incognoscível, e representações fenomênicas). De fato, a pergunta de Nietzsche, citada acima, é uma provocação direcionada às tentativas de depreciar o corpo, empreendidas nas mais diversas filosofias, que nunca o consideraram um órgão capaz de pensar e de produzir conhecimento; é também uma denúncia de outras dualidades metafísicas, muito exploradas em seu filosofar: verdade e mentira, essência e aparência, mundo verdadeiro e mundo falso, alma e corpo, e, ainda, a crença num além imutável, onde habitaria o solitário e eterno sujeito transcendental. Nietzsche, opondo-se às tradições filosóficas mencionadas e, notadamente, contra o idealismo, defende que o corpo carrega em seu todo a possibilidade de conhecer, na medida em que a consciência não é o órgão supremo do conhecimento, mas o próprio corpo conduz a busca por descobrir e inventar o mundo circundante. Nesse sentido, a interpretação nietzschiana do corpo reforça o entendimento inovador do filósofo a respeito da natureza e da liberdade: ambas escapam do controle racional e atuam sobre o agir humano sem que a consciência possa interferir de maneira imediata (ou seja, o agir e pensar consciente, de acordo com a perspectiva nietzschiana, atuaria a posteriori).

Segundo Nietzsche, valorizar o conhecimento racional, limitado a abstrações vazias de carnalidade, é consequência, também, da má compreensão da consciência (não somente do corpo); de fato, conforme o filósofo, haveria uma crença de que o intelecto seria autossuficiente e independente de qualquer vínculo corporal. Por isso, Nietzsche afirma que a consciência "é o último e derradeiro desenvolvimento do orgânico e, por conseguinte, também o que nele é mais inacabado e menos forte" (aforismo 11, GC; 2004c, p. 62). Percebe-se, assim, a noção de natureza enquanto inocência do vir-a-ser, relacionada ao desenvolvimento dos organismos (seres vivos em geral, seres humanos, em particular), na medida em que o filósofo considera fortemente os aspectos não racionais do comportamento humano; segundo o autor, foram os instintos, por mais precários e insuficientes, que garantiram a permanência da humanidade enquanto espécie; caso contrário, diz Nietzsche, a humanidade 
"pereceria por seus juízos equivocados e seu fantasiar de olhos abertos, [...], em suma, por sua consciência" (GC, \#11).

Ainda que Nietzsche não elabore uma biologia celular ou genética, suas declarações mostram a importância das dimensões biológicas humanas, severas vezes negadas pela Filosofia. Por isso, o filósofo desconstrói a hierarquia (valorativa) que sobrepõe a consciência às demais partes do corpo, como se os indivíduos fossem composições justapostas sem vínculos interdependentes entre as partes. $\mathrm{E}$ mais do que hierarquizar, as filosofias e o senso comum consideram a consciência o centro de todo indivíduo: "Pensam que nela [consciência] está o âmago do ser humano [...]! Tomam a consciência por uma firme grandeza dada!" (GC, \#11). O resultado de centralizar o consciente é a crença de que haveria uma essência humana, cravada na própria alma; seria acreditar que nós, seres humanos, somos portadores de um dom sagrado e divino, a consciência, e a partir dessa marca de superioridade seria possível afirmar a não-animalidade humana: a distinção entre animais (irracionais) e humanidade (racional). Nietzsche, ao contrário de exaltar a razão e a consciência, apresenta uma filosofia transvalorativa, ou uma transvaloração de todos os valores, através da qual o conhecimento não se limita à racionalidade, mas se trata de um processo em que o corpo e a consciência atuam juntos, sem separações e sem papeis fixos para cada parte desempenhar. Notadamente, a filosofia nietzschiana desafia a pensar sem dualismos ou sistemas limitativos, conforme afirma o filósofo: "A tarefa de incorporar o saber e torna-lo instintivo é ainda inteiramente nova, apenas começa a despontar para o olho humano" (NIETZSCHE, 2004, p. 63); nesta perspectiva inovadora para o século XIX, conhecer é incorporar o saber até que se torne instintivo, corporal, não restrito ao plano racional.

Não há dualidade corpo e alma em Nietzsche, porém, suas ideias parecem apontar para uma noção de natureza (humana) guiada por instintos, em oposição à razão - conforme já indicado. Seria uma outra concepção dual que apenas inverteria os sistemas precedentes? O lugar da consciência seria ocupado pelos instintos e no lugar da alma o corpo seria exaltado? Embora aberta a interpretações, a perspectiva aqui adotada sobre a filosofia nietzschiana permite afirmar que não se trata de mera 
inversão dualista; os sistemas dualistas são caminhos dos quais Nietzsche se desvia no decorrer de toda a sua obra. De certo, quando o filósofo desvaloriza a consciência por ter sido a última a se desenvolver e, por conta dessa limitação orgânica, atuar precariamente, tem-se a impressão de que ele supervaloriza os instintos corporais; contudo, a crítica à razão não significa a defesa de uma natureza ou essência humana instintiva. Trata-se, fundamentalmente, de revelar o "desconhecido mundo do sujeito" (conf. o aforismo 116 de Aurora); desse modo, Nietzsche promove uma transvaloração quando destitui a consciência de todos os valores atribuídos a ela e, ainda, ressalta a nossa auto-ignorância e a impossibilidade de um conhecimento puramente racional da subjetividade humana.

Os esquemas dualistas denunciados por Nietzsche separam, também, sujeito e objeto, interioridade e mundo exterior, conforme o autor escreve no aforismo 346 de A Gaia Ciência: “já rimos, ao ver 'homem $e$ mundo' colocados um ao lado do outro, separados tão-somente pela sublime presunção da palavrinha 'e'!" (2004c, p. 239). Separar homem e mundo é um dos feitos das filosofias e ciência modernas, ao defenderem a objetividade do conhecimento (científico) - e esta separação não se restringe aos contemporâneos do filósofo, mas adentra o século $\mathrm{XX}$, até surgirem críticas ao objetivismo e ao subjetivismo. Nietzsche rejeita o pensamento dualista e o descarta em seu perspectivismo. De certa forma, o filósofo consegue acertar as contas com o passado risível da Filosofia, combatendo dualismos caducos e fazendo perguntas improváveis, como no aforismo 354 de $A$ Gaia Ciência: "Para que então a consciência, quando no essencial ela é supérflua?". A provocação é desconcertante: ora, como a própria Filosofia seria possível sem consciência? Mas no mesmo aforismo, Nietzsche apresenta uma utilidade à consciência: a necessidade de comunicação e compreensão entre as pessoas. Tornar-se consciente foi necessário para a espécie humana justamente porque a necessidade comunicativa não era suprida pelos instintos; segundo o autor, o surgimento da consciência só se justifica porque a falta de respostas orgânicas pressionou o desenvolvimento desse órgão tão precário, a seu ver. 
O intelecto é a mais frágil e precária parte do organismo humano, de acordo com Nietzsche. Em suas palavras: ao longo dos tempos, o ser humano - o "animal mais ameaçado" que já existiu - necessitava de "ajuda, proteção, precisava de seus iguais, tinha de saber exprimir seu apuro e fazer-se compreensível" e porque seus instintos não supriam as necessidades de convivência, de vida em conjunto, gregária, um órgão é gradativamente estimulado a se desenvolver para desvincular o homem do comportamento puramente instintivo, animalizado; a exigência comunicativacompreensiva supre, então, a carência gerada pelos instintos e permite aos homens um saber bastante específico: “'saber' como se sentia, 'saber' o que pensava” (af. 354, GC; 2004c, p. 249). A consciência é a tradução compreensível de múltiplos processos incompreensíveis, atuantes simultaneamente em cada existência, conforme afirma:

\begin{abstract}
Pois, dizendo-o mais uma vez: o ser humano, como toda criatura viva, pensa continuamente, mas não o sabe; o pensar que se torna consciente é apenas a parte menor, a mais superficial, a pior, digamos: - pois apenas esse pensar consciente ocorre em palavras, ou seja, em signos de comunicação, com o que se revela a origem da própria consciência. [...] Acrescente-se que não só a linguagem serve de ponte entre um ser humano e outro, mas também o olhar, o toque, o gesto... (af. 354, GC; 2004c, p. 249 - todos os itálicos em citações são do próprio autor).
\end{abstract}

Embora empregue os termos superficial e pior para se referir ao pensar que se torna consciente, não se trata de uma nova hierarquia entre corpo e consciência (conforme já mencionado). As palavras do filósofo alertam para a ilusão de acreditar-se consciente de tudo, como o Deus onisciente judaico-cristão e como expressa Descartes, ao forjar o cogito (penso, logo sou meu pensamento). O saber consciente, aquele que é verbalizado na linguagem, é considerado, por Nietzsche, superficial e incompleto. A transvaloração filosófica nietzschiana mostra que não é só a linguagem, expressa em signos padronizados, que transmite as mensagens do conhecimento; ao contrário de se limitar ao âmbito racional, Nietzsche afirma que o olhar, os gestos, os toques, as posturas corporais engendram saberes que prescindem da consciência para serem reconhecidos.

Se a consciência expressa a "natureza comunitária e gregária" da espécie humana, conforme conclui o autor no aforismo citado acima, isto não pressupõe, porém, uma existência cooperativa e pacífica entre os indivíduos. Apesar de 
possibilitar a vida em sociedade (condição de existência de ser humano e de se humanizar), para o filósofo, a consciência é uma doença cujos sintomas são as crenças, a busca por verdade, a alta confiança depositada no saber (gramática, ciência, metafísica) e a (falsa) certeza de que ser consciente é estar no controle de tudo e de si mesmo (ações, sentimentos, sensações). Mais uma vez, acentua-se a relação proposta anteriormente, entre natureza, inocência, acaso e liberdade. A noção de que a ponte entre intenção e ato permanece desconhecida, apresentada por Nietzsche em Humano e Aurora ganha, em A Gaia Ciência, maior sustentação, na medida em que o autor estabelece um papel coadjuvante para a atuação da consciência. E, ainda que "o homem inventor de signos" seja cada vez mais "consciente de si" (af. 354, GC; 2004c, p. 249), este saber-se-de-si nunca se esgota e nunca é suficiente. Pois Nietzsche é categórico ao afirmar que não há um "órgão para o conhecer, para a 'verdade': nós 'sabemos' (ou cremos e imaginamos) exatamente tanto quanto pode ser útil ao interesse [...] da espécie: e mesmo o que aqui se chama 'utilidade' é, afinal, apenas uma crença” (af. 354, GC; 2004c, p. 250). Em suma, a consciência atuante no ser humano aproveita-se da autoilusão de comando para tentar assumir, efetivamente, o comando; contudo, é um esforço em vão: não se pode afirmar a supremacia da consciência e, tampouco, sobressai-se daí uma dominação comandada exclusivamente pelo corpo, visto que os instintos são insuficientes para garantir a existência e sobrevivência da espécie humana.

As críticas à consciência expostas n'A Gaia Ciência também aparecem no romance filosófico Assim falou Zaratustra, confirmando a continuidade e a afinidade teórica entre as obras precedentes. Através dos discursos de Zaratustra, o filósofo esclarece o que é, afinal, o corpo, e por que ele é uma grande razão. Antes, é preciso reafirmar a inseparabilidade entre consciência e corporalidade: trata-se da mesma relação inseparável entre o livre agir e o inocente fluir da natureza ou entre as mãos que lançam os dados (necessidade) e o resultado alcançado (acaso transformado em destino); essas imagens evocam, ainda, uma força irracional e irrefreável que, subitamente, nos atravessa (tema a ser discutido nas considerações finais do artigo). Por ora, cabe analisar o discurso "Dos desprezadores do corpo", capítulo exposto na 
primeira parte de Assim falou Zaratustra. Embora Nietzsche se refira ao corpo como uma grande razão, não se trata de fixar o domínio do corpo sobre o intelecto, como se a dimensão corporal fosse dotada de racionalidade (razão).

No discurso de Zaratustra, a inusitada frase: "O corpo é uma grande razão, uma multiplicidade com um único sentido, uma guerra e uma paz" (NIETZSCHE, 2005 , p. 60), traz à tona a ideia de múltiplas forças que lutam e se reconciliam, seguidamente. E, assim, a grande razão torna-se compreensível quando confrontada à pequena razão: e o que seriam essas grandezas? Seria mais um provocativo jogo de palavras de Nietzsche para mostrar que os conceitos não carregam suas definições neles mesmos? Se sim, a jogada pode ser entendida como uma brincadeira com a palavra "razão", tão celebrada pelos filósofos e que, para Nietzsche, representa o modo de pensar da moral: obediência aos princípios de identidade, causalidade, nãocontradição e verdade. Pequena razão se refere, justamente, ao precário órgão da consciência, duramente criticado em GC. Haveria uma grande razão, o corpo, e outra, menor, que seria a consciência. É esta a imagem que Nietzsche evoca nas palavras de Zaratustra. Assim, Nietzsche supera a dualidade corpo e alma e estabelece uma continuidade entre corpo e razão, na qual a consciência é a expressão verbalizada (racional) de um fluxo corporal inconstante.

É no corpo mesmo que os atos e pensamentos se formam, sem controle prévio da consciência, mas num emaranhado, no qual não se separam causas e efeitos: "é o teu corpo a sua grande razão: esta não diz eu, mas faz o eu" (NIETZSCHE, 2005, p. 60). Nota-se aí a diferença posta por Nietzsche entre dizer e fazer o que se define por "eu"; este é feito de corporeidade e não de abstrações metafísicas; ou seja, não é a alma ou o espírito que fazem o eu, mas uma combinação de carne, ossos, sangue, etc. Também se destacam, nesse processo, as hierarquias entre grande e pequena razão; o recurso permite ressaltar a grandiosidade de tudo que escapa à consciência para fazer o eu - para constituir o humano, demasiado humano. Além de ser feito de corporeidade, de acordo com o filósofo, o eu domina e é dominado por um ser próprio, que poderia ser nomeado de inconsciente - mas o termo evoca um conceito caro à psicanálise e não cabe, aqui, apresentar essa dimensão conceitual. Logo, o lado não- 
consciente do eu será considerado por Nietzsche num sentido carnal: "o ser próprio procura também com os olhos dos sentidos, escuta também com os ouvidos do espírito. [...] Domina e é, também, o dominador do eu. [...]. Mora no teu corpo, é o teu corpo" (NIETZSCHE, 2005, p. 60).

Agora, mais uma imagem é posta em cena: há uma grande razão, inicialmente chamada de corpo, em contraposição à pequena razão (consciência), e o ser-próprio, morador do corpo e do eu, capaz de olhar e escutar com os sentidos do espírito. Mas de que espírito se trata, se não há nem deuses nem almas nessa filosofia? Mais uma vez Nietzsche zomba do pensar filosófico, usando estruturas duais (corpo e espírito) para depois desconstruí-las, deixando uma única estrutura chamada ser-próprio, que faz eu. Assim, a consciência expressa uma força pequena diante da grande razão que é o corpo, e o ser-próprio envolve o corpo e o espírito (no sentido de não-consciente), também criado junto às demais partes da composição: "O corpo criador criou o espírito como mão da sua vontade" (NIETZSCHE, 2005, p. 61); o espírito (alma/intelecto) não seria, então, mais uma obra divina, mas brotaria do próprio corpo humano em desenvolvimento. Portanto, nesse discurso, Nietzsche indica um elo criado entre corpo e consciência, que revela a criação do intelecto enquanto resultado de uma necessidade corporal, de atuar através de maiores habilidades, como se o corpo precisasse se expressar também de modo simbólico. Nessa perspectiva nietzschiana, a insuficiência do saber instintivo provocou o surgimento da consciência - conforme visto. O espírito (consciência, alma) é criação do corpo, na medida em que um não poderia existir sem o outro: além de ser corpo, a humanidade desenvolveu o saber de si mesma; é uma sabedoria corporal, um vínculo inseparável entre corporeidade e intelecto, que pode ser traduzida numa imagem banal: o ato de mover a mão só se realiza se houverem mãos para serem movidas e vontade para ordenar o movimento. Mas, se não há separação entre corpo e alma, por que há sociedades que criam regras para reprimirem severamente a espontaneidade corporal e tudo que exala animalidade e natureza? 
Considerações finais: vontade, coragem e vida

A filosofia nietzschiana é, sobretudo, um alerta contra a vida em rebanho, conforme afirmado no início do artigo. De fato, Nietzsche mostra que, frequentemente, o gado humano obedece a comandos, sem pensar sobre como está sendo afetado: as ovelhas seguem o pastor sem duvidarem do que é imposto a elas. Ao mesmo tempo, algumas tradições filosóficas instituem preconceitos fundados sobre a distinção corpo e intelecto e, em consequência, afirmam a supremacia da razão em detrimento da corporeidade; negam aspectos de animalidade presentes na conduta humana e, desse modo, constroem um conceito limitado de liberdade, incompatível com o desconhecido mundo subjetivo que habita cada ser humano. Essas táticas de negação da corporeidade (natureza/animalidade) são empregadas pela moral de rebanho imposta nas sociedades, ao longo dos tempos. Em outros termos, a negação do corpo (ou a má compreensão do corpo) é uma forma de negar natureza e liberdade, de acordo com a perspectiva nietzschiana, aqui adotada. Por outro lado, há os espíritos livres e os andarilhos representando o que Nietzsche nomeia de grande libertação. Nesta perspectiva, a liberdade está atrelada à natureza, mas não de um modo determinista, pois é o jogo do acaso que está em curso - jogo no qual os dados lançados não obedecem a uma lógica racional ou divina; ao contrário, Nietzsche mostra que é necessário ocorrer cada jogada, para construir o próprio fluxo da vida. Está aí o vínculo entre natureza, liberdade, acaso, irresponsabilidade e inocência. E em relação à constituição humana, o filósofo afirma que a consciência não ocupa o centro da existência; dessa forma, Nietzsche considera a dimensão corporal de maneira ampla, pois o corpo é composto de forças que o regem e atuam mais intensamente no organismo humano do que o pensamento racional. Assim, a unidade corpo-consciência torna-se mais compreensível quando se compreende que, na filosofia nietzschiana, liberdade é correlata à natureza. Não é uma visão romantizada sobre o estágio natural humano (nunca efetivamente descoberto), mas uma ideia de que não há controle racional da existência; ao contrário, é a irresponsabilidade dos acasos que reinam e regem o mundo; por isso, o filósofo 
critica as tentativas de controlar e adequar os indivíduos em parâmetros prédeterminados pela moralidade (sociedade de rebanho).

Dizer que o corpo é uma grande razão é aceitar que há forças incontroláveis agindo em conjunto; noutras palavras, é saber agir, deixando a natureza agir, assumindo que nem o corpo nem a consciência dirigem as ações humanas o tempo todo. Neste ponto, o filósofo acrescenta, ainda, um fator atuante em todos os seres: a Vontade. Vontade de poder, ou de potência - dependendo da tradução ${ }^{8}$. Vontade que expressa possibilidades múltiplas; fluxo de vontade que extravasa em todos os seres. Natureza e liberdade são expressões da vontade de poder - corpo e consciência também. No aforismo 349 de $A$ Gaia Ciência, o conceito de vontade de poder expressa a ideia de que a natureza não é uma luta por conservação e sobrevivência, com finalidade evolutiva, mas uma luta por abundância, desperdício e irracionalidade: "a luta grande e pequena gira sempre em torno da preponderância, de crescimento e expansão, de poder, conforme a vontade de poder, que é justamente vontade de vida" (af. 349, GC; 2004c, p. 244). A vontade extravasa e extrapola qualquer barreira colocada em seu caminho, como numa tempestade em alto mar. Esta é uma adequada metáfora explicativa: o oceano pode ser comparado à vontade de poder, assim como o vento e a tempestade podem ser as forças atuantes (vontade atua sobre vontade, afirma Nietzsche); nessa metáfora, as ondas representam a parte visível das forças e ações de todos os seres - nos humanos, é o que Nietzsche definiu por grande razão, eu, corporeidade, instintos-impulsos-pulsões. O barco seria a ilusão de

\footnotetext{
${ }^{8}$ Em A doutrina da vontade de poder em Nietzsche, de Wolfgang Müller-Lauter, há duas explicações sobre as possibilidades de tradução do termo nietzschiano Wille zur Marcht; primeiramente, Scarlett Marton declara sua opção por utilizar vontade de potência e não poder, devido ao uso político do termo; e ainda que possa induzir a uma "conotação aristotélica", a autora afirma que "a vontade de potência é força plástica, criadora. É o impulso de toda força a efetivar-se” (MARTON, S. in: MULLER-LAUTER, 1997, p.10). A segunda interpretação é de Oswaldo Giacoia Jr., optando por vontade de poder, para ressaltar "uma concepção de força e poder se esgotando, sem resíduos, a cada momento de sua efetivação" (GIACOIA JR., in: MULLER-LAUTER, 1997, p. 52). Sem pretensão de tomar partido de uma das traduções, penso que "poder" - purificando-o do teor político - expressa possibilidades e esta é uma atribuição da vontade na filosofia de Nietzsche: são múltiplas forças possíveis atuantes simultaneamente. E o autor do livro citado, conclui sua obra afirmando a dimensão interpretativa aberta com a noção de vontade de poder: "Aumento de poder significa obtenção de novas perspectivas [...] e com isso alargamento das interpretações" (MULLER-LAUTER, 1997, p. 149). Pluralidade e possibilidades são atributos da vontade em questão.
} 
autocontrole ou pequena razão, intelecto, consciência. E quem navega o barco? Que papel tem o navegante do barco em meio à tormenta? Afinal, o que é Vontade? ${ }^{9}$

Nietzsche afirma a vontade de poder não no sentido de ato intencional, controlável; não é agir de acordo com a própria vontade, como uma escolha de conduta. Vontade de poder, na imagem proposta aqui, é o próprio oceano; mas ela não está restrita ao oceano; ela atua nas forças que formam as ondas, atua nos ventos, na tempestade e, até mesmo, sobre o barco: o casco pode, num movimento brusco, furar e encher de água na proa, as velas podem ser resgadas. A vontade pode, inclusive, afundar o barco. Em resumo, um naufrágio não é resultado de uma única força, mas de todas as forças atuantes em conjunto. Nietzsche, através de um discurso de Zaratustra, define, enfim, o que é vontade: "onde encontrei vida, encontrei vontade de poder" (Za, "Do superar a si mesmo"; 2005, p. 145). Vontade de poder engloba todos os termos apresentados até aqui: natureza, necessidade, liberdade, acaso, inocência, irresponsabilidade, corpo e consciência. De fato, mesmo a consciência não é um órgão fixo e autônomo: ela é atravessada pela vontade de poder; e assim também o corpo está sempre em movimento, nunca se fixa nem permanece numa única forma; a cada instante uma força é superada por outra. É como o movimento das ondas quebrando na praia, sem nenhuma finalidade ou controle.

Observar as ondas do mar é o que faz a nossa consciência diante das forças que atuam incessantemente em nós. Esta é a dinâmica da vontade de poder: infinitas possibilidades num fluxo imprevisível. Assim, Nietzsche apresenta a vontade de poder enquanto conceito que abrange acaso-natureza-liberdade e atua na grande e pequena razão, na unidade corpo-consciência. A partir dessa perspectiva, a vontade nietzschiana pode ser entendida como vontade criadora; Zaratustra afirma: "O querer liberta: é esta a verdadeira doutrina da vontade e liberdade" (Za, "Nas ilhas

\footnotetext{
${ }^{9}$ Miguel Angel de Barrenechea, em Nietzsche e o corpo, emprega a imagem do mar e das ondas para esclarecer que "vontade de potência é o próprio processo de efetivação das forças, não algo exterior a elas" (BARRENECHEA, 2017, p. 80 - grifos do autor). Assim, a metáfora do mar exprime a inseparabilidade entre vontade e forças atuantes: "só há onda - força - integrada no devir de todas as forças que constituem o mar - a vontade de potência” (BARRENECHEA, 2017, p. 81). Na imagem evocada aqui foram acrescentados os elementos da tempestade, do barco e de seus tripulantes enfrentando a tormenta e as ondas gigantes em alto mar - uma releitura poética da metáfora que expressa com precisão a vontade de poder.
} 
bem-aventuradas"; 2005, p. 116). Assumir o querer é libertar-se também da postura reativa de "nada querer" (quietude da vontade, diria Schopenhauer, em Mundo como Vontade e Representação) ou de, passivamente, seguir o rebanho e as restrições niveladoras da moral.

Por fim, restam alguns questionamentos: se a vontade de poder é incontrolável como uma tempestade no oceano, como lidar com essa imensidão oceânica? Como agir para não se afogar em alto mar? Ora, Nietzsche responderia através de uma fala de Zaratustra: "somente quem sabe para onde vai sabe, também, que vento é bom e favorável à sua navegação" (Za, Parte IV, "A sombra"; 2005, p. 321). Mais do que um conselho, Nietzsche oferece um caminho. E se navegar é preciso, quem navega prepara o próprio barco, lança as velas na direção do vento e, ainda que a vida seja imprecisa, conseguirá navegar. Este é o papel atribuído aos navegantes e à tripulação do barco em meio à tormenta; quem navega o barco deve se preparar para as múltiplas possibilidades, vividas a partir do momento em que a navegação se inicia. Há tempestades a serem enfrentadas diariamente. Nesse ponto, Zaratustra oferece mais um conselho, não somente a quem se arrisca em alto mar, mas a quem não quer ver a própria vida naufragar: é preciso coragem; "a coragem é o melhor matador, a coragem que acomete; mata, ainda, a morte, porque diz: 'Era isso, a vida? Pois muito bem! Outra vez!" (Za, Parte III, "Da visão e do enigma"; 2005, p. 192). Encarar a vida com coragem é não sucumbir diante do fluxo da vontade e de suas tempestades imprevisíveis. Vontade de poder, enfim, reúne liberdade e natureza, corporeidade e intelecto, numa atitude, necessariamente, criadora: "se há inocência em meu conhecimento, tal acontece porque há nele vontade de procriação. [...]; do mesmo modo é o martelo impelido para a pedra. Ah, dorme na pedra para mim, ó homens, uma estátua, a imagem das minhas imagens! [...] Quero concluir a estátua" (Za, "Nas ilhas bem-aventuradas"; 2005, p. 116). Concluindo, é assim que Nietzsche encara as tormentas da vida, construindo um pensamento em perspectiva, transvalorativo, e que resiste além do tempo (sem naufragar). 


\section{REFERÊNCIAS}

BARRENECHEA, Miguel A. Nietzsche e a liberdade. Rio de Janeiro: 7Letras 2008. . Nietzsche e o corpo. $2^{\mathrm{a}}$ ed., Rio de Janeiro: 7Letras, 2017.

DESCARTES, R. Meditações. Trad. J. Guinsburg e Bento Prado Jr. Os Pensadores, São Paulo: Abril Cultural, 1979.

GIACOIA JR., Oswaldo. Nietzsche: o humano como memória e como promessa. Petrópolis, Editora Vozes, $2^{\mathrm{a}}$ ed., 2014.

MÜLLER-LAUTER, Wolfgang. A doutrina da vontade de poder em Nietzsche. Apresentação de Scarlett Marton. Tradução de Oswaldo Giacoia Jr. São Paulo: Annablume, 1997.

NIETZSCHE, F. Humano, demasiado humano: um livro para espíritos livres. Trad. Paulo César de Souza. São Paulo, Cia das Letras, 2004a.

Aurora: reflexões sobre os preconceitos morais. Trad. Paulo César de Souza. São Paulo, Cia das Letras, 2004b. A Gaia Ciência. Trad. Paulo C. Souza. São Paulo: Cia das Letras, 2004c.

2005. Assim falou Zaratustra. Trad. Mário da Silva. RJ: Civilização Brasileira, Ecce Homo - como alguém se torna o que é. Trad. Paulo C. Souza. São Paulo: Cia das Letras, 2004. 